\title{
Paula Pustułka
}

\section{SWPS University of Social Sciences and Humanities}

\section{Natalia Juchniewicz}

SWPS University of Social Sciences and Humanities Institute of Philosophy, University of Warsaw

\section{Izabela Grabowska}

SWPS University of Social Sciences and Humanities Centre of Migration Research, University of Warsaw

\section{Participant Recruitment Challenges in Researching Peer Groups and Migration Retrospectively}

DOI: http://dx.doi.org/10.18778/1733-8069.13.4.04

Abstract This paper discusses the challenges of researching peer groups through a multi-focal, temporal lens in a retrospective manner. Embedded in a broader "Peer Groups \& Migration" Qualitative Longitudinal Study (QLS), the article focuses on recruiting young respondents (aged 19-34 at present) who originally come from one of the three medium-sized towns in Polish localities and are either migrants or stayers connected to mobile individuals. The respondents are tracked retrospectively and asked to discuss their adolescence, as well encouraged to provide contacts to their youth Peer Group members. Based on fieldwork experiences and field access challenges, four models of recruiting migrants' high school peer groups are presented. Furthermore, variants and rationales of non-recruitment are also provided. Focusing on the process of establishing a long-term and large-scale peer panel in the QLS, the paper contributes detailed know-how and strategies around participant recruitment.

Keywords participant recruitment, migration, peer group, Qualitative Longitudinal Research (QLR), longitudinal study

Paula Pustułka has a PhD in Sociology from Bangor University in Wales (2015) and is currently a Postdoctoral Researcher and Lecturer at the SWPS University of Social Sciences and Humanities in Warsaw. Her research includes projects on Peer Groups \& Migration, Transnational Polish Fami- lies in Norway (Transfam), and Polish Migrant Motherhood in the West. Paula works in qualitative and mix-methods traditions, specializing in ethnographic approaches. She has extensively published on the nexus of family, gender, and migration. email address: ppustulka@swps.edu.pl
Natalia Juchniewicz PhD in Philosophy, Assistant Professor in the Institute of Philosophy at the University of Warsaw, PhD Student at the Interdisciplinary Doctoral Studies Program at the SWPS University of Social Sciences and Humanities in Warsaw and Postdoctoral Researcher in the project Peer Groups \& Migration. Natalia is interested in new media, technology, mobility, and qualitative ethnographic research. email address: n.juchniewicz@uw.edu.pl

Izabela Grabowska is Professor at University of Social Sciences and Humanities in Warsaw and the Director of the Interdisciplinary Doctoral School. Izabela is an

Introduction: Researching Youth Biographies through Time

In order to best highlight the core challenges of the participant recruitment for the Qualitative Longitudinal Study (QLS) carried out for the Peer Groups and Migration $^{1}$ project, we begin with a simple question: what would you do if a social researcher came to interview you about your youth of your high school time? If you are like most people studied in the past, you would be likely to reminisce about your past and might quite enjoy revisiting and sharing your memories from adolescence. This is partially true because people generally like to share their stories (Ortiz 2001; Seidman 2013), whilst those related to youth usually evoke a sense of one's formatively emotional and intellectual journey (Berndt and

elected Deputy Chair of IMISCOE Research Network Board of Directors and member of Executive Board, as well as IMISCOE Coordinator at the Center of Migration Research, University of Warsaw. She publishes internationally on labor market and human capital, social and geographical mobility and development with social remittances. Her recent book projects include Movers and Stayers: Social Mobility, Migration and Skills $(2012,2016)$ and a co-authored monograph Migrants as Agents of Change. Social Remittances in an Enlarged European Union (2017, Palgrave Macmillan). More at: www. izabelagrabowska.com

email address: izabela.grabowska@swps.edu.pl

Keefe 1995; Allan 1998; Arnett 2007). Even though research tended to emphasize the problematic youth condition (see e.g. Urberg et al. 1997; a critique by Males 1996), one's individual period of being young is still rather remembered as a carefree and spontaneous phase of exploration (Skelton et al. 1998), prime time of making lasting friendships (Allan 1998; 2011; Crosnoe et al. 2003), and the biographical moment of "coming of age" in a sense of reorienting from family environment to a peer group (PG) setting (Youniss and Smollar 1985; Males 1996; Arnett 2007).

However, this partially retrospective individual interview we discuss here - in the project's case taking place with a migrant - is only the first step of the envisaged Peer Groups and Migration QLS. Let us now specify: how would you react to research-

${ }^{1}$ The project, titled Education-to-domestic and-foreign labor market transitions of youth: The role of locality, peer group and new me-
dia (abbreviated to Peer-Groups \& Migration), is funded by the Polish National Science Center under the Sonata Bis Project Contract No. 2015/18/E/HS6/00147. ers not only probing you about friends from your youth, but also asking you to provide contact details as that they also wished to speak to them as 
well? Through the QLS in the Peer Groups \& Migration project, we have learned how these "conversations," which essentially translate into a success or failure of a recruitment procedure, may transpire. Therefore, the key topic of this article is to present methodological challenges and best practices of recruiting PGs which existed during adolescence (i.e. the 15-19-years of age period of post-secondary school) among young adults (representing the age group from 19 to 34 at the time of the first wave of the QLS in 2016). The main contribution revolves around the strategies of building a lasting and large-scale peer panel.

What instantaneously comes to mind is a question about the extent of the temporal horizons within the project. More specifically, it has to be noted that young people aged 19 to 34 were invited to take part, which means that the time that has passed since their adolescence varied from respondent to respondent, ranging from just a few years, to nearing one and a half decades. This posed the first challenge as to how to dynamically conceptualize and account for the effects of the passage of time in social research (Adam 2008; Neale 2013; 2017; Thomson and McLeod 2015). Besides temporal distance, perhaps more important is the actual relational composition (Kinney 1993; McCabe 2016; Pustułka et al. forthcoming) of a given individual's PG. Notably, while some friendships survived the test of time, other relationships evolved and changed with regard to shape and membership constitution. Some PGs continued to exist in a more or less same form of affine relationships, yet, more often than not, our migrant respondents' PGs from adolescence no longer existed.
The dissolution of a PG founded and operating through one's high-school years is not surprising and had been commonly noted (though not studied) in earlier research, which tends to focus on friendships in general (Allan 1998). Still, reaching the contacts of the initial Ego/Alpha respondent was paramount for the success of the project, as those Other/Alter individuals serve as a direct comparative population for gauging the effects of migration and education on the current employment and life-trajectories of youth (see Grabowska et al. 2017a). Discerning and mitigating the reasons for the Ego/Alpha not being in touch with their former peer-group became instrumental, whilst alternative strategies for finding respondents needed to be devised.

Moreover, the QLS methodology assumes that the relation between researcher and participant of the project needs to be grounded in trust and willingness to continue contact in the future. It is highlighted in research connected with access to the closed and self-organized communities (Eide and Allen 2005). Sustainability of a connection through time also means that the researcher is in possession of a considerable amount of personal, sensitive, and delicate information about the respondent. There is not only an unequal power dynamics involved, but somewhat one-sided relations can mean that participants expect reciprocity (Tang 2002; Seidman 2013). This means that relationships between people are very dynamic and need to be open to unexpected behaviors and negotiations (Lynn-McHale and Deatrick 2000). For this particular project the aspect of trust is highly important (DeLaine 2000; Seidman 2013), because it is not only the problem between a researcher and a person interviewed, but also between the researchers and peer-group members.

Investigating difficulties and benefits of retrospectively researching PGs from the young people's adolescence, this paper proceeds with a short discussion of the QLS methodology, as well as typical approaches favored by youth studies, also with reference to examining peer relationships and youth friendships. Then, we briefly recall the broader approach of the Peer Groups \& Migration project. In the core section of empirical illustrations, we depict models of recruitment and (non)-recruitment found during the first wave of our QLS, while the final section is dedicated to offering some conclusions about the chosen methodology and its contribution.

Choosing QLR for Studying Youth, Peer Groups and Migration

In order to grasp the complexity of the project, we apply the methodology of Qualitative Longitudinal Research (QLR) developed and promoted by Neale (Neale and Flowerdew 2003; Neale 2013; 2017; Grabowska and Sarnowska 2017). We approach individuals in PGs in three selected local communities in Poland and walk alongside with them throughout the course of three research waves (36 months).

QLR can be defined as a qualitative inquiry that is conducted in a dynamic relation to time and space (Neale 2013; 2017). The approach draws on ethnography, social anthropology, history, and community and theater studies. Over the past decade or so, scholars promoted these methods as a distinctive way to understand the textured social world and "social change in the making" (Saldana 2003; Neale and Flowerdew 2003) with a growing importance of migration in it (Krings et al. 2013; Grabowska et al. 2017b). Only through time we are able to grasp the nature of peer-groups, and only through time we are able to discern how personal and social, the micro, meso and macro, agency, and structure are connected and how they come to be transformed in a dynamic way (Neale 2017).

In youth studies, the topic of PG has been predominantly researched from the perspective of early socialization (kindergarten and early school PGs), internal peer pressure, relations and culture (including belonging to youth sub-cultures) and from the perspective of class-related PG behaviors, especially popular in the 1980s (Willis 1977).There has also been a broader notable transition from problematizing and scapegoating youth to empowering them as social agents (Males 1996). This coincides with a revival of generational research (Strauss and Howe 1991; Howe and Strauss 2009), as looking at PGs evokes how sociologists can understand "differences between age groups and locate individuals and groups within historical time" (Pilcher 1994). Going back to Mannheim (1952), generational location captivates one's existential determination of knowledge, and points to certain modes of behavior, feelings, and thought. The formative experience of youth and early adulthood should be seen as biographical moments during which generations are formed, with the respective generational consciousness related to the pace of social change (Strauss and Howe 1991; Pilcher 1994). In that sense, researching generations is vital for discerning the rhythm of history (Mannheim 1952:286) since the biological life-spans are interwoven with the social fabric and may result 
in the creation of generational units, divides, and fissures. Not unlike Strauss and Howe (1991:43053), the project seeks to look at life course cycle as diagonal and depicts "lived history" through cross-generational relationships between cohort-groups. We argue that PGs can be seen as a lens to the microcosm of generations.

More recently, the term peer group has been contested, collated with "friendship networks" (McCabe 2016), and marked by definitional uncertainties. Nevertheless, a PG is understood as "an individual's small, relatively intimate group of peers who interact on a regular basis" (Ryan 2000:102). Mirroring the notion of a "clique," it is a "collection of individuals with whom the individual identifies and affiliates and from whom the individual seeks acceptance or approval" (Astin 1993:400; see also Willis 1977: 23). For these micro-processes to take place, a PG is usually seen as relatively small, with an average of five to six members, but possibly also including dyads and larger groups of up to 12 members (Berndt and Keefe 1995; Urberg et al. 1997; Ryan 2000). It is also typical for adolescents to form multiple peer groups and, notably, it is considered research best practice to ask the respondent for self-nomination of friends that belong to their group(s) (Ryan 2000), as it has been done in this project (see also Grabowska et al. 2017a; Pustułka et al. forthcoming). To sum up, the peer groups are something informal and created as discrete social spaces. They are made through relations (often friendships) and through shared significant events which can manifest the meaning of peer cultures. They convey recurrent or unique experience in certain localities and behaviors of certain individuals (Corsaro and Eder 1990).
The junction of migration and youth is explored in the project through a qualitative longitudinal approach. The use of QLS (Neale and Flowerdew 2003; Neale 2013; 2017) is dictated primarily by the fact that young lives are commonly in flux, and the fact that the approach combines extended temporal perspective of looking at "sociological" content of what, why, and how the trajectories of young people unravel. For the biographies of the contemporary 19 to 34-year-olds, a mere one year can make a tremendous difference with respect to crossing over to adulthood (Arnett 2007; Heath et al. 2009), so this study responds to the ideas of textured social world and "social change in the making" (Ritchie and Lewis 2003; Saldana 2003; Thomson and Holland 2003).

Different markers of transition may also be observed, as sequent stages of the project's interviewing waves may depict reaching certain markers of adulthood - from finishing education, to establishing one's own household, to marriage, to having children, et cetera. (e.g. Arnett 2007; Heath et al. 2009). While the latter is the "prospective" dimension of the study, the examination of youth period in the lives of the respondents constitutes a "retrospective" aspect, their "backstory" (Figure 1). In a sense, we become "time travellers" (McLeod and Thomson 2009) in a research conducive to reflexivity, reconfigurations and constraints. It is evident that time implicitly complicated relationships of the respondents who began their transitions from education to labor market at the same locality, yet operated in various employment settings due to internal and international mobility (see also Jones 1999), thus creating a temporal and spatial matrix.
Figure 1. Prospective and retrospective view in the QLS

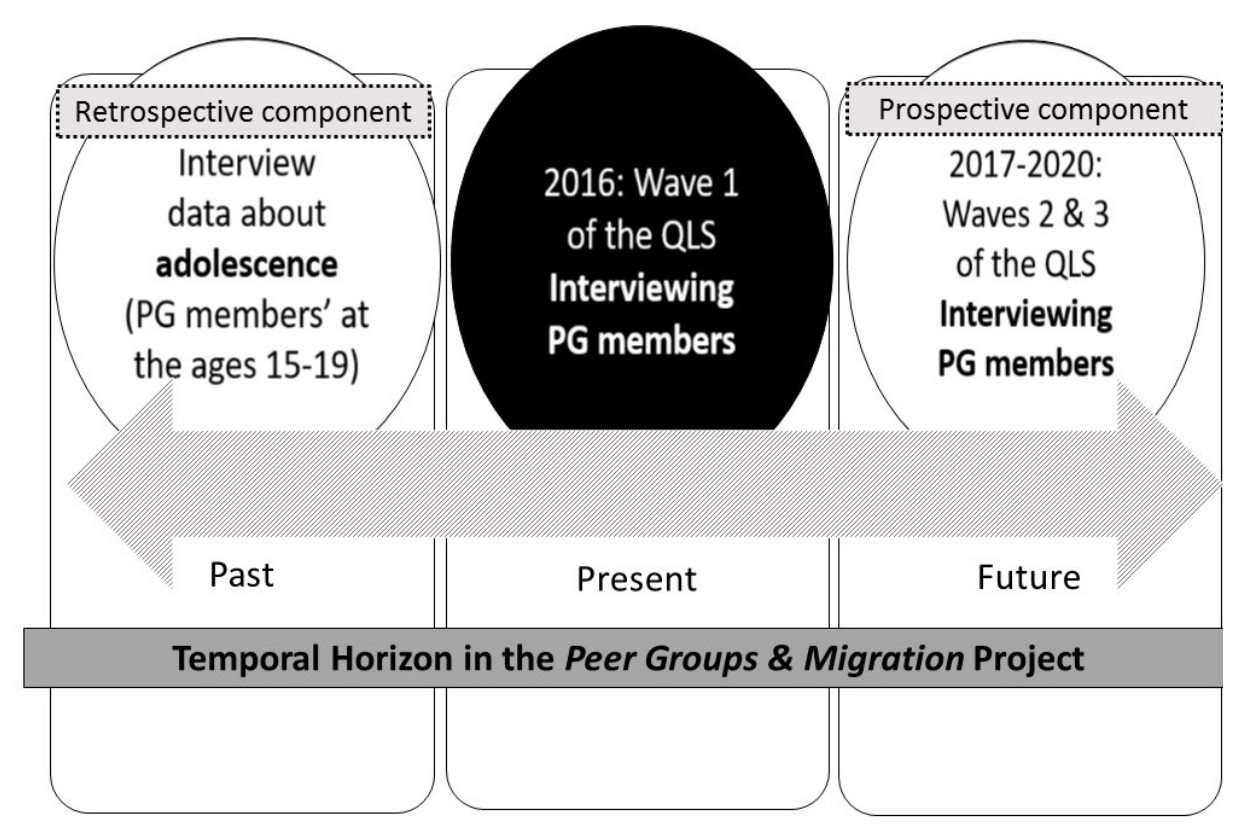

Source: Own elaboration.

The look into peer groups harnesses a chance to capture a process of "dwelling among friends" (Fischer 1982), highlighting the paths of stayers and movers from one locality and one small friendship unit both side-by-side (comparatively) and relationally. This QLS is a journey of walking alongside the respondents (McLeod and Thomson 2009), while accounting for the people and places they encounter, cherish, or leave behind. A roadmap to the QLS is given in Table 1 below.

Table 1. Roadmap of QLS in the Peer Groups \& Migration project

\begin{tabular}{|c|c|c|c|}
\hline FRAME & $\begin{array}{c}\text { WAVE } 1 \\
\text { FALL 2016/17 }\end{array}$ & $\begin{array}{c}\text { WAVE } 2 \\
\text { FALL 2017/18 }\end{array}$ & $\begin{array}{c}\text { WAVE } 3 \\
\text { FALL 2018/19 }\end{array}$ \\
\hline $\begin{array}{l}\text { Macro: Local } \\
\text { community }\end{array}$ & $\begin{array}{l}\text { Ethnographic screening of } \\
\text { local communities }\end{array}$ & $\begin{array}{c}\text { Significant others from local } \\
\text { community indicated by } \\
\text { peers }\end{array}$ & $\begin{array}{l}\text { Monitoring local trends } \\
\text { and activities (institutions, } \\
\text { projects, individuals-local } \\
\text { actors) }\end{array}$ \\
\hline $\begin{array}{l}\text { Meso: Peer group, } \\
\text { family, new media }\end{array}$ & $\begin{array}{l}\text { Mapping peer groups from } \\
\text { adolescence }\end{array}$ & $\begin{array}{l}\text { Life-cycle of a PG (current } \\
\text { personal communities) } \\
\text { Socialization agents } \\
\text { Role of new media in peer } \\
\text { group and migration }\end{array}$ & $\begin{array}{l}\text { Life-course of a secondary } \\
\text { school PG } \\
\text { Current peer groups } \\
\text { (mapping for comparisons) }\end{array}$ \\
\hline $\begin{array}{l}\text { Micro: Trajectories } \\
\text { and transitions }\end{array}$ & $\begin{array}{l}\text { Education and employment } \\
\text { trajectories (detailed } \\
\text { sequences) } \\
\text { School-to-work transitions }\end{array}$ & $\begin{array}{c}\text { Trajectories' update } \\
\text { Big } 5 \text { markers of transitions } \\
\text { to adulthood }\end{array}$ & $\begin{array}{c}\text { Trajectories' update } \\
\begin{array}{c}\text { Personal traits, competencies } \\
\text { and social skills }\end{array}\end{array}$ \\
\hline
\end{tabular}

Source: Updated from Grabowska et al. 2017a: 17 
In this paper, a clear focus is on the people and their relationships - both the ongoing and the long-broken friendships. The QLS is further embedded in Layder's (1998) sociological practice, which means that the research process is creative rather than prescriptive. In that sense, altering the envisaged "ide$\mathrm{al}^{\prime \prime}$ recruitment procedures should not be seen as "fixing," but rather as a responsive and appropriate innovation (see also Amit 2003).

Recruiting Participants: Strategies, Channels, and Challenges

In the broader literature, the strategies of recruiting participants for qualitative research has been discussed quite extensively (e.g. Arcury and Quandt 1999; Neufeld et al. 2001, McLean and Cambell 2003; Eide and Allen 2005; Rugkåsa and Canvin 2011,). Longitudinal scholars have expanded the focus to elaborating on the temporal issues around attrition and retention throughout subsequent waves within research projects (Thompson and Holland 2003; Saldana 2003; Patrick 2012), also in the context of young people (Weller 2010). This also concerns the Peer Groups \& Migration project, where we approach and encounter classical longitudinal cohorts, which are "aggregates of individuals who experience the same life event between the same time interval" (Ruspini 2002: 9). Our cohorts encompass peer groups' members who share similarity of age (19 to 34), as well as generational past of the broader societal and historical events (see Patrick 2012; Neale 2017). Chief among them were the Polish 1989 transition, a major educational reforms of the Polish system that the young respondents were at the center of, as well as Poland's accession to the EU in 2004, among others.
What is more, the selection was limited to the people originating from three localities, namely the medium-sized towns of Mielec, Puławy, and Słupsk, representing different regions of Poland. The decision to research peer-groups from these localities was motivated by similarities between these towns in the structural and social dimension, especially with reference to the pre-existing migration cultures. All towns boasted highly developed networks of secondary schooling of different types and broadly offered some menial job opportunities through Special Economic Zones. For all towns, quality tertiary education was not attainable locally, hence fostering internal mobility. In terms of discrepancies, migration patterns varied, as they were historically constituted on regional issues ${ }^{2}$. There were also pragmatic reasons for choosing these middle-towns, in particular an insider within the research team and already established researchers' networks in these localities.

In general, the strategy of recruitment appeared quite straightforward in a sequence: we were to seek out a migrant (international permanent/ seasonal migrant or an international returnee migrant) from a given town. This meant that the recruitment strategy for the study began from the solicitation of the Ego/Alpha migrant contact, who then led us to their PG members - Alters/Others. The initial recruitment channels for Ego/Alpha participants comprised researchers' personal networks and their contacts, suggestions of potential respondents acquired

${ }^{2}$ The selection of these localities was deliberate. A detailed comparison and description can be found in Grabowska et al. 2017a. In this article, we focus on the matters of the field-access rather than the field itself. during the ethnographic fieldwork with experts across the three towns, as well as targeted social media campaigns run predominantly on Facebook. In the ideal case-scenario setting, an international migrant identified through the aforementioned channels would have provided contacts to his or her PG members. Clearly, a preferred form of contact details would entail phone number rather than less reliable social network channels (see Figure 2). An ideal recruitment hinged upon Ego/Alpha migrant who was encouraged to act as a project ambassador and "co-recruit" the members of his or her PG into the panel study. It is vital to note that everyone was informed prior to an interview that the researchers are interested in broader peer groups and the expectation of sharing contacts was made explicit.

Figure 2. Recruitment: Optimal Strategy

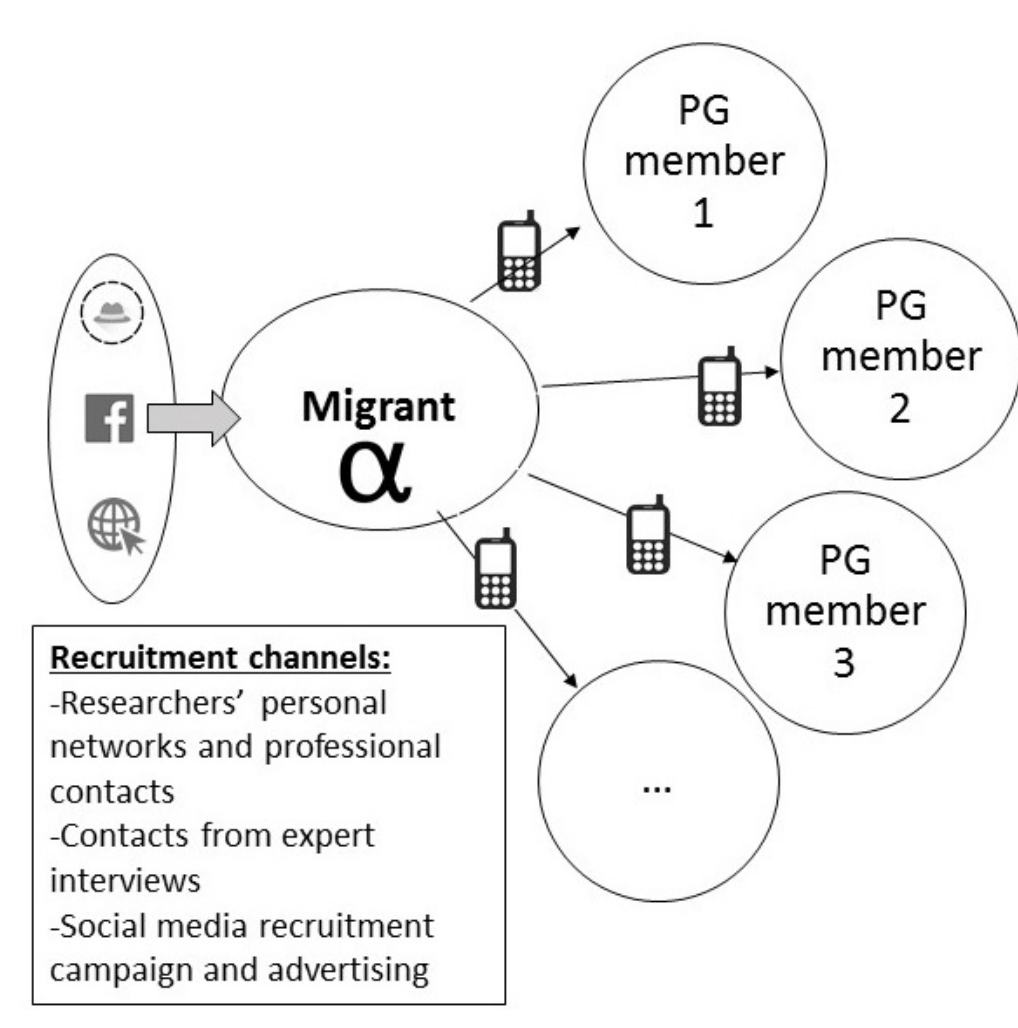

Source: Own elaboration.
Before moving on, it should be noted that the project expectedly carried some ethical challenges due to having a three-partisan consent, privacy and anonymity contract between the Research Team, initial Alpha respondent, and each of his or her contacts. As already mentioned, Alpha (and later Beta) contacts were asked to invite others, yet were asked about sensitive issues around providing with contact details, with researchers never pushing for details that respondents did not want to provide. In fact, migrant individuals interviewed first could decide not to assist with co-recruitment with no implications or further requests. Insider Researcher was an exception to this rule, but again only stepped in when explicitly instructed to do so by Alpha and unconditionally accepted lack of answer as absence of consent to participate. She similarly remained reflexive about her own double-status and dual positionality, as some respondents sometimes unexpectedly tied her to their PG networks and included in their narratives. This was handled in a way that ensured protection of both the researcher and the respondents.

No research material has been shared between interviewees, which means, for example, that we did not come with Alpha's reconstruction of the PG to their contacts (later respondents), but rather allowed for unmatched mapping. While this led to inconclusive results regarding some PGs' composition, it ensured internal privacy and unbiased reconstructions of personal relations. Finally, in adhering to ethical best practice procedures (DeLaine 2000), each respondent 
had to sign an individual consent form at the beginning of the interview. In fact, respondents consented three times: after an initial contact, upon setting up an interview, and while signing a written agreement about participation and audio-recording. All three steps were required. At the stage of data analysis, all personal details have been anonymized to prevent identification.

Within the research process, the realities of recruitment turned out to be marked by certain immediate and more long-term challenges. First and foremost, it has to be underscored that the migration patterns in the three towns quickly pointed to the challenge in Puławy, which appeared to statistically have fewer international migrants visible through the recruitment channels. To solve this issue, the sequence has been shifted to recruiting a Beta contact first. That person needed to be an internal migrant (a person who moved away from Puławy to another town in Poland), and the assumption was that ultimately their peer groups will reveal migrant members.

Secondly, as Facebook campaign surprisingly did not yield many voluntary declarations of willingness to participate, the reliance on personal networks grew. In this context, it has to be mentioned that the field access in the three localities varied with respect to having a "team insider" in Mielec (which is the hometown of one of the team members), boasting help of efficient "insider assistants" in Słupsk (using two students from this town who go to the University where the project team is based) and to being at a disadvantage of no insider aid in Puławy. While this ultimately did not great- ly impact the number of interviews/PGs, the pace of recruitment was markedly different and mirrored the level of the pre-existing insider gateways. However, in the context of Facebook as a tool for recruiting respondents to the project, it is important to indicate that it was used also in a more personal manner and not only in the official recruitment campaigns. Researchers in the project announced on their personal websites that they were looking for young people in the age of 19-34 from the above towns. This yielded personal network contacts, though, in many cases, required considerable amount of efforts and information-sharing through private messaging for people to agree to take part in the study (see also Baltar and Brunet 2012; Kosinski et al. 2015).

Once again, regardless of the recruitment channel and prior to obtaining informed consent, it has been explained what the research entails and that the contacts to members of the respondent's peer group(s) would be solicited. However, this seemed to only partially register with our Ego/Alpha contacts as a key step of the project, so their later dedication to relaying contact information for friends from adolescence varied greatly. Finally, while the classic approach would be to establish a clean database of phone numbers and emails, it was to be expected that - due to the passage of time - not all of the people would have that kind of data for their (former) friends. Under this premise, the contact details were often scarce and included unreliable details for Facebook and other social media accounts, just a name of somebody's workplace, no longer active phone number/email, and so on. Moreover, it was rather clear that the young peo- ple's lives are extremely hectic and busy (Colvile 2016), so in some cases the original plan that the interviews should ideally take place on a faceto-face basis had to be abandoned. Further, this communication problem was exacerbated by the fact that the PG members are globally scattered. While this was expected with the project focused on migrants, it meant that many Alphas were only attainable by phone/Skype. In sum, some PG members were available for interviews in their home towns or larger Polish cities (Warsaw, Cracow), but it was obviously impossible to interview those living around Europe and beyond (e.g. in the US) on a face-to-face basis. Therefore, a number of interviews were conducted over Skype, Facebook Messengers video-chat feature, or by telephone. These conversations were audio-recorded.

In sum, after considerable efforts, 133 individual interviews were conducted for Wave 1 of this QLS. Twenty four PGs were mapped, specifically ten in Mielec, eight in Słupsk and six in Puławy, respectively. In addition, five dyads were mapped, whilst as many as twenty-three young adults became Ego/Alphas with no PGs, either due to not having a PG, or because it turned out impossible to reach their contacts. Therefore, it is clear that many scenarios of the follow-up recruitment and instances of non-recruitment have taken place in this study. We will now illustrate these with cases of specific PGs, but what has to be noted is that only the first wave of the QLS is covered here, so the sequent interviews might elicit alternative recruitment patterns in the face of attrition and the ever-evolving personal relationships between the interviewees.
Model 1: Alpha-driven straightforward PG recruitment

Under the first scenario, a near ideal situation of the willingness and dedication to take part in the project could be observed as the pre-modelled recruitment in Figure 2 above. An example can be consulted in Figure 3 with the PG of $\mathrm{Kosia}^{3}$, who is a 32-year-old international return migrant originally from Mielec. Note that the diagrams of the mapped PGs include both the interviewed (circled) and non-interviewed significant others listed by the Ego/Alpha contact. We use additional icons to discern how slowly or quickly the contact information was acquired and the interview conducted, while also illustrating which communication channels were available and used.

Going back to the example at hand, Kosia (Ego/Alpha) quickly devised a map of her PG members after being interviewed in Warsaw. For the majority of her PG members, she provided telephone numbers. Kosia further informed her closest friends about the project. Though Ewka lives in another town and Monisia is in Warsaw, it was possible to conduct Skype interviews with them within a week after Kosia's original interview. Conversely, the attempts to contact Felix and Mariusz by email were not successful, Felix's phone number turned out to be out-of-service, and the two boys were eventually not interviewed. Still, mapping a triad of girls was deemed sufficient for the purpose of the project.

${ }_{3}^{3}$ All names used in the diagrams have been changed to pseudonyms. For some cases, other biographical details - like occupation- were also altered with respect to protecting anonymity
of the respondents. 
Figure 3. Alpha-driven straightforward recruitment: Kosia

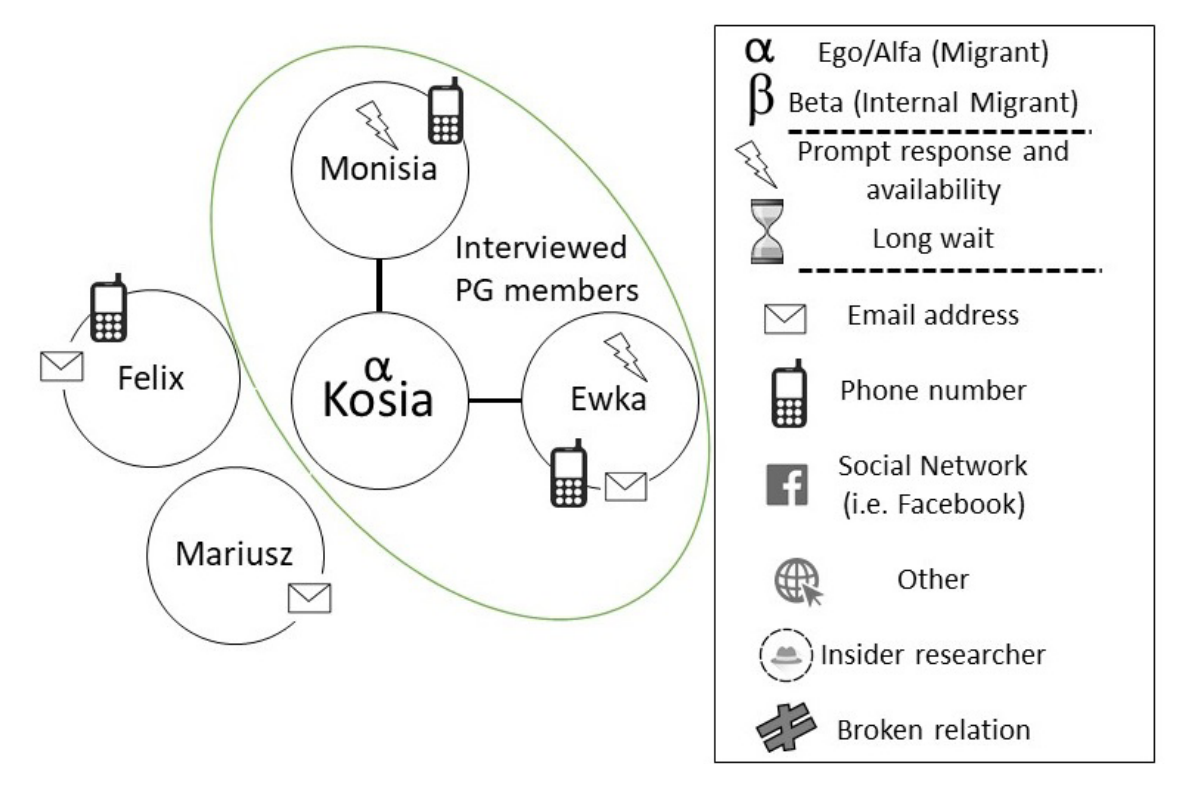

recently came back from a long-term migration to the United Kingdom. Dorota was initially recruit ed as an acquaintance of a student gate-keeper at the SWSP University. Since the very beginning, Dorota was very eager to take part in the interview and had a strong conviction that the project was important. The meeting with Dorota was conducted face-to-face and took place in Warsaw, where she has been living since returning to Poland several weeks prior. Dorota provided phone numbers for all her peer-group members (see Figure 4) in an extremely prompt fashion because she has been staying in touch with most of them ever since high--school.

In this case, a crucial aspect of success was the excitement of the Ego/Alpha who became an advocate and advertised the project. While straightforward and prompt mapping of a PG was extremely rare, certain

Figure 4. Alpha-driven straightforward recruitment: Dorota individuals' efforts were instrumental in achieving the research goals. Quite crucially, in the case above Ewka and Monisia did not map one another, so they were key contacts for Kosia only, and attaining their details without her peer-researcher mitigating involvement (see also Ryan et al. 2011) would have been impossible.

Another example of the Alpha-driven straightforward re-

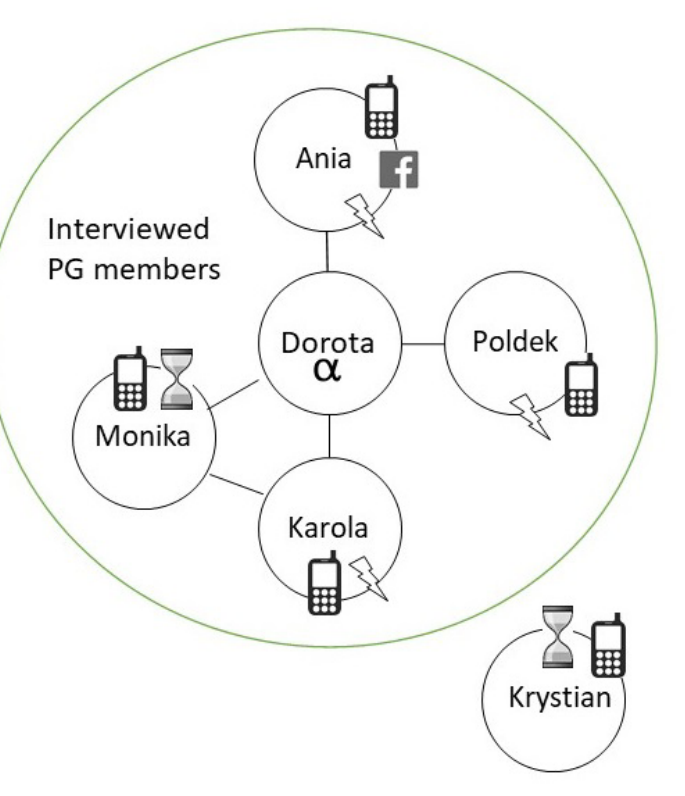
cruitment occurred in the case of
Three interviews were conducted in the same month. One of those interviewees - Karola - had additional contact details for Monika, which made it possible for an interview to take place after three months since the original interview with Dorota. Still, one person from Dorota's list did not stay in touch with the researcher after the initial phone call, illustrating that initial consent sometimes did not yield participation (see also Saldana 2003; Patrick 2012).

Model 2: Alpha-driven chain recruitment

A second and less straightforward model of soliciting participants was largely linked to two processes of a 'chain recruitment' on the one hand, and simple matters of availability on the other hand. In this case, the Ego/Alpha contact was Radek (b.1983) who currently lives in Cracow. He was a seasonal migrant to the UK and originally comes from Mielec. Although his high-school PG is not a tight-knit clique anymore, they are still friends who meet when they can, even though two PG members live abroad.

Shortly after a face-to-face interview, Radek had left for a business trip to Canada and understandably fell out of touch with the researcher. Only after some time, he connected the researcher to one of his PG members - Daria - via Facebook chat. Since Daria was simply added to a chat window with a one-liner explanation of what the communication is about, the recruitment had been much more of a challenge. Further, as Daria is a medical doctor living in a dif- ferent timezone, setting up an interview took long. Meanwhile, the attempts to encourage Radek to advertise the project to his other contacts did not yield, and it is unknown to the researchers whether information was not relayed, or Miły refused to partake.

Figure 5. Alpha-driven chain recruitment: Radek

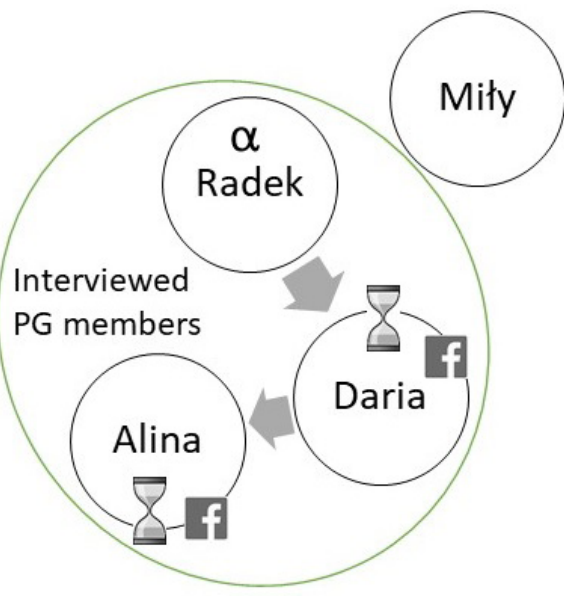

$\begin{array}{cc}\alpha & \text { Ego/Alfa (Migrant) } \\ \beta \text { Beta (Internal Migrant) } \\ \text { Prompt response and } \\ \text { availability } \\ \text { Long wait } \\ \text { Email address } \\ \text { Phone number } \\ \text { Social Network } \\ \text { (i.e. Facebook) } \\ \text { OE Other } \\ \text { (3) Insider researcher } \\ \text { Broken relation }\end{array}$

Source: Own elaboration

As the interview with Daria finally took place, it turned out that she could connect the researcher to Alina, meaning that a particular type of a chain-recruitment was executed in this PG's case. As much time had once again passed since Alina found the time for an interview, a three-member PG had been mapped just as Wave 1 of the QLS concluded.

\section{Model 3: Beta-led recruitment}

The recruitment of Beta respondents, who are internal migrants (i.e. they migrate from the town of origin to another town in Poland), was an idea especially 
applied to the Puławy location. It was necessary because finding external/international migrants from this town in the specified age group was difficult. A somewhat "hidden" migration culture operates in this town (see Grabowska et al. 2017b). The main assumption for such creative recruitment strategies (see Patrick 2012) was to expand the general network of Puławy-contacts. Secondly, it was presumed that the Beta Contact is likely to have international migrants as members of their PGs. These contacts then became indirectly recruited as Ego/Alpha. Thus, the Beta recruitment gave access to the two different types of interviewees. First type of the interviewees was unhelpful from the point of view of the project's goals and constituted a non-recruitment variant described later in this article. The second type was successful, that is, Betas had international migrants in their PG.

The second type of Beta-interviewee is Asia who was mentioned by one Ego/Alpha from Puławy as a person who knows many people and has access to local elites. She shone as a "gatekeeper" to the location and further PGs. The first contact with Asia was via Facebook: she quickly responded to an interview request and met with the researcher in Warsaw. Asia eagerly described the period of her youth and her PG, furnishing contacts to many people. What is especially important is that Asia provided contact details to Oliwia, who was an international migrant. She further helped to establish contact with her via Facebook because Oliwa was still abroad. Notably, Asia described people from her PG in a very detailed manner, which was very helpful for the researchers who sought to understand the atmosphere among individuals in the group. In this particular case, Beta contact became an Alter/Other of the Ego/Alpha - Oliwia.

Figure 6. Beta-led recruitment: Oliwia \& Asia

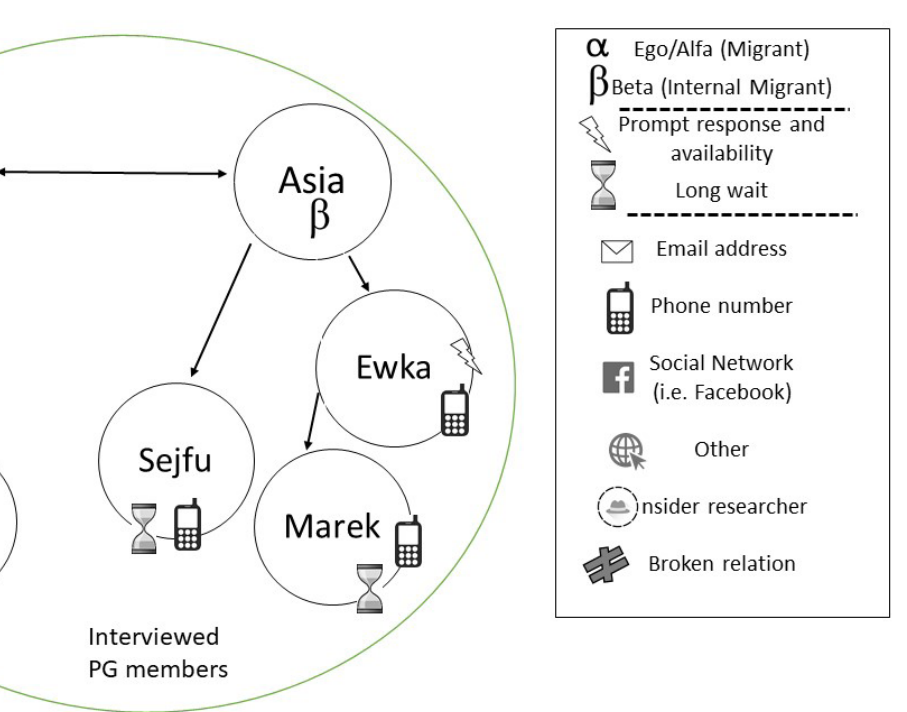

Source: Own elaboration

It should be emphasized that Oliwia was much less forthcoming and descriptive about locality of origin and PG members during her interview, which means that only the accumulation of the two perspectives from Ego/Alpha and Beta/Alter allowed for a more holistic and complete picture of this PG to emerge. Oliwia and Asia gave phone numbers to other PG members, so it was not difficult for the researchers to contact the remaining respondents. Interestingly, it was Asia who was treated by the members of this PG as a leader and a reference to her name when arranging the interview was usually helpful to "break the ice." Three interviews were conducted face-to-face, two via telephone, and one on Skype. The mapping of this peer-group was spread in time and it took about three months to complete the interviews, but, being a rarity in this type of projects (see Saldana 2003; Thomson and McLeod 2015; Neale 2017), all people asked to participate had agreed to become members of the QLS panel.

\section{Model 4: Mixed recruitment}

The most common recruitment pattern entailed a combination of the aforementioned models, further supplemented by creative strategies. For instance, let us look at the case of Sandra's (b.1983) PG below. An important feature of this PG is the fact that the researcher from Mielec knew Sandra from the neighborhood in early childhood. The Ego/Alpha respondent graduated technical school and moved to Italy at the age of 19, only to return to her hometown three years ago. After a face-to-face interview, Sandra provided Facebook contacts for two of her school friends - one abroad and one still in Mielec. She also informed both about the project, though, paradoxically, it was easier to set up an interview with Isia who lives abroad than with Arletta who is based in Mielec.

Figure 7. Mixed recruitment: Sandra

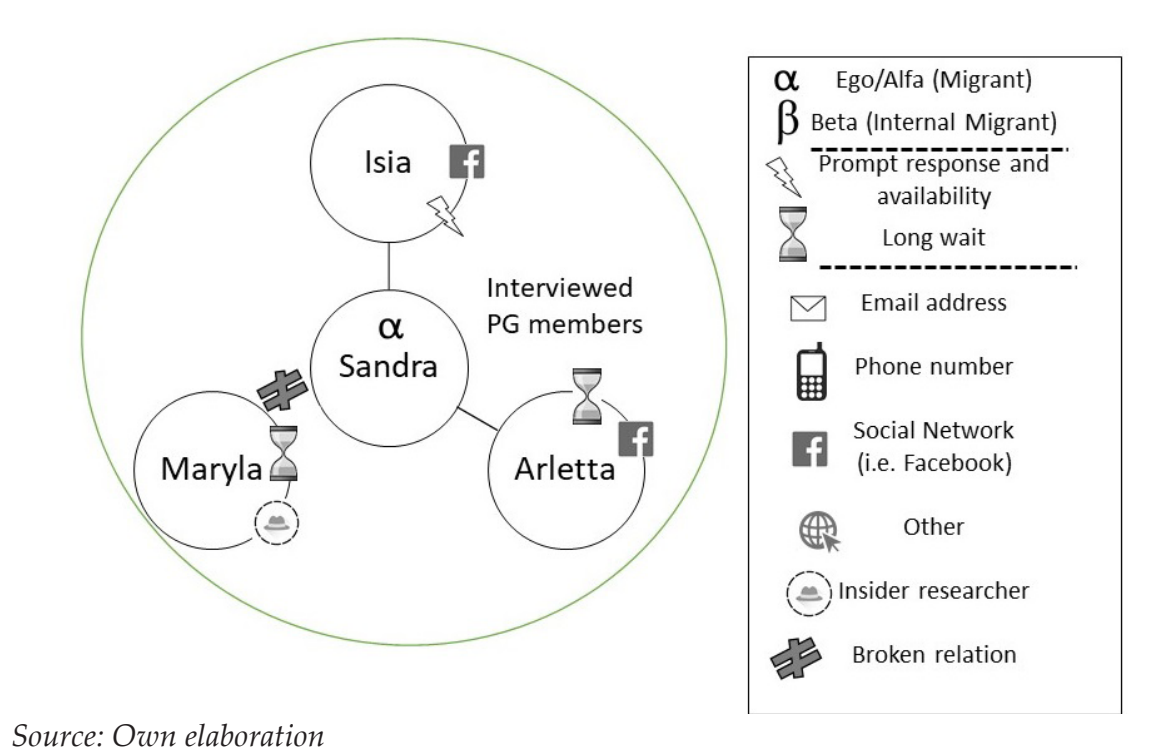

The problem emerged when Sandra was asked about Maryla. The Ego/Alpha's relationship with this PG member had ended years ago. Though Sandra knew that Maryla came back from emigration, they had neither been in touch, nor was she able (or willing) to supply any form of details. It was a matter of fate that the researcher happened to also know Maryla through Sandra since childhood and Alpha encouraged the researcher to use the connection. This was a case of an intensive recruitment, as the researcher needed to leave a message with a contact request for Maryla at her workplace (a shop) and only this permitted a more complete PG mapping.

Mixed recruitment was also typical for larger PGs, as was the case for Mirek's massive microcosm of adolescent friendships (see Figure 8). In this case, Mirek's relationships with a majority of his PG's members are perfunctory or even ruptured. During the interview, it transpired that the researcher who comes from the same town coincidentally knows some of the contacts mentioned, even though she and the respondent did not know each other during their adolescent years. After a tactful probing, an agreement had been reached that Mirek can provide details for reaching three to four people, which eventually yielded interviews with Kornelia and Nina. In the second step, the researcher reached out to Joanna, Tolek, and Beata on being instructed to do so by Mirek. Interviewing Beata unveiled that the PG continues to be in operation, even though our Ego/Alpha contact was no longer a member. Beata, however, was at the center of the network, so she was 
able to provide contact details for additional PG members (Kamil, Stefan) originally indicated, but unreachable through Mirek.

but were no longer in contact with the majority of their then-friends. Thirdly, the defining moment of the PG seems to have been a conflict between the former best friends Mirek and Konrad, which illuminates how a single event can disrupt a clique, hinder field access, as well as impede retention for longitudinal research.

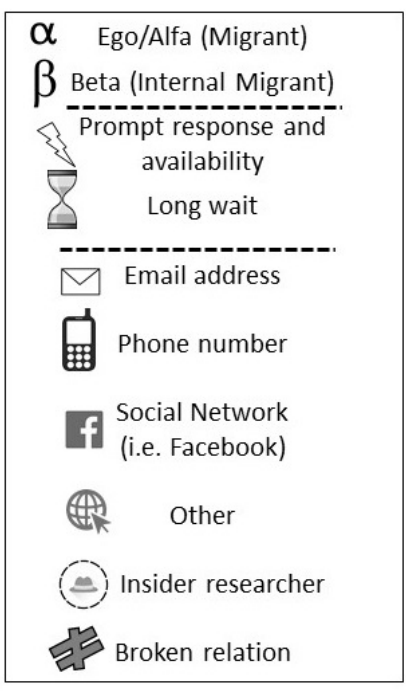

All in all, the major challenge of Beta-led and Mixed recruitment models ( $3 \& 4)$ pertained to the fact that despite being initially demarcated as PG members by Ego/Alpha, the respondents who were reached via Beta or other channels (e.g. insider researcher) had a tendency not to map the original contact. To clarify with an example,

Noteworthy in the case of this PG is that an array of mixed recruitment strategies needed to map this group nearly ten years after the Ego/Alpha's exit from the clique. Firstly, the role of an insider researcher should be emphasized. It appears that in case of loosened or broken friendship relationships, it might be easier for an external yet familiar person to intervene and invite people to take part. In other words, invitations extended by the researcher were just as successful as those normally issued by Ego/Alpha contacts in different PG settings. Secondly, the fissure within the group which started at the closure of high school education - can be observed in how a subgroup of the original PG revolves around Beata (Beta/Alter). The remaining ex-members of the PG function more as free electrons: they reminisced about adolescence, Mirek had clearly noted Kamil, Tolek, and Stefan as his PG members, yet those three respondents did not mark Mirek as their PG members, even though they all included Beata (Beta) as a relation marked by propinquity. This, however, fits into a broader discussion about people's divergent memories and understanding of a PG, as well as notions about significant others changing through time (see Saldana

\section{Variants of Non-recruitment}

Having analysed the "success stories" of PG recruitment, it is indispensable to comment also on efforts that did not lead to PG mapping. Noteworthy is the fact that non-recruitment could mean a cessation of mapping at Ego/Alpha (an individual respondent without a PG in the panel), a limitation of a PG to a mapped dyad or triad in spite of the known larger 2003; Allan 2011). original size of the clique (e.g. having three out of five PG members in the panel), as well as simple absence of significant others in certain PGs (e.g. a person mapped as crucially important for several participants does not make it into the panel). Different justifications were found in relation to "no access" to participants, as well as standard refusals (see Patrick 2012). These reasons and rationales constitute data in itself, as they tell stories about the condition of personal bonds between people from the same PGs over time (see also Allan 1998; 2011).

First and foremost, in the majority of cases it was impossible to actually determine a cause of a non-participation and the researchers could only speculate about Ego/Alpha's simply not asking people, supplied emails/phone numbers being outdated, or just the fact that people were too busy or unwilling to participate. While the latter is typical for all social research which relies on voluntary participation (DeLaine 2000, Ritchie and Lewis 2003; Seidman 2013), an additional dimension here revolves around the potential strain that rehashing one's past might effectuate (see also Neufeld et al. 2001; Ortiz 2001). In other words, this goes back to the originally foregrounded argument that a person (Ego/Alpha) might truly enjoy talking about their story while concurrently having the full capacity and a guaranteed right to decide that they do not want to get back in touch with people from their past for a variety of reasons at a given moment in time. In addition, there were rare occurrences of interviewing international migrants who turned out not to have had a PG during adolescence. The recounted reasons for this situation pertained to spending time with other people (e.g. family members), or even having negative experiences of loneliness due to mobbing or bullying. Such stories, especially connected with having no PG as a result of social exclusion were very emotional and sensitive. In some cases interview needed to be broken to give participants a moment for calming down when painful situations were recalled. What is important in the context of the project's main focus on mobility, having no PG could sometimes constitute one of the push factors for migration as no significant others in the local networks kept an individual in place.

Another feature of the project was a strategy to rely on Beta-interviews in Puławy, which was productive for many, but not all PGs. One unsuccessful Beta-interviewee was Klaudia who was indicated by a Facebook friend and agreed to an interview with no hesitation. During a face-to-face meeting in Warsaw Klaudia revealed many important issues about Puławy locality, but she was a rather reserved person during adolescence and noted having only two friends at that time. No PG members ever migrated abroad, so Klaudia chose not to provide contacts. The recruitment has concluded here with a single non-migrant respondent.

One of the most common rationales behind people not relaying contacts to their PG members encapsulated relational ruptures (see also Allan 1998; 2011). Many different motives were supplied here, ranging from an argument or a breakup in adolescence, to a later divergence in lifestyle choices or values. Practical reasons were also at play: as people started to move around, their relationships became lax and/ or strained. Examples of raptures could be tracked above, as Mirek's best friend Kamil was mapped as 
important PG member by nearly all other respondents, yet he declined to participate in the study. Quite often a rupture was also rather declarative, as people lost touch, but nevertheless knew about their former friends' lives from Facebook. In that sense, Mirek had detailed information about Kamil's work situation (including company name) and his recent nuptials, despite an evident "bad blood" between them.

Less dramatic yet actually more frequent case of non-recruitment was connected with the tempo of contemporary life and common experience of just being too busy. In several cases, the members of PGs were jettisoning between countries and continents, leading what appeared to be very intensive professional and personal lives. It can be stipulated that more women in the sample are somewhat due to the particular time in this cohort's life, namely the fact that many respondents are transitioning to parenthood. Broadly speaking, young mothers were typically available for Skype/phone interviews, while access to the high-flyer men was very rare (e.g. inaccessible male PG members included a successful musician, a young politician, a corporate lawyer, etc.).

\section{Conclusions}

The methodological challenges with the recruitment process of PGs mirror the unfolding structures of adolescent friendships through time. As they constitute dynamic tales of a generation "in the making" and "in transition," they can be studied for their effects upon the broader social history (Strauss and Howe 1991; Howe and Strauss 2009). Nevertheless, arriving at the rich data about twenty-four PGs was difficult right from the start, as recruiting migrant participants and their friends from adolescence into a QLS was complex, time-consuming, and not always successful. On the basic level, it is clear that relations change between people over time and not all of them could be maintained for various reasons (Allan 1998; 2011). This resonated in our PG mapping research procedure, which unveiled individuals with various types of PGs (Pustułka et al. forthcoming) and reflected the structure of the society where not everyone has a PG or continues to be involved in friendships formed during their youth (Fischer 1982; Youniss and Smolar 1985; Allan 1998; McCabe 2016).

Retrospective recruitment of peer groups from adolescence was first and foremost more challenging than anticipated. While the migrant respondents were relatively easy to identify and convince to take part, mapping a minimum triad PG usually took about two months, if it was attainable at all. A clear implication is that skilled, trained and experienced researchers are needed to get access and track people in spite of their relationships being altered through time. The access to PG was expectedly the easiest when the friendships still existed and Ego/Alpha could easily share contacts to other PG members. This underscores the overall undervalued potential of researching friendship (Allan 1998; 2011; Crosnoe et al. 2003), especially as a relatively uncharted territory of Polish sociological research. We see that PGs varied from the accessible, to semi-accessible, and to inaccessible. This contention means that we had to unconditionally embrace the available field and take advantage of all available recruitment channels to achieve sustainability of participation (e.g. Arcury and Quandt, 1999; Amit 2003, Eide and Allen 2005; Weller 2010; Patrick 2012).

In the project, the situation where access was uncertain depended on someone else who could be a gatekeeper, for example, Beta (secondary contact/an internal migrant), corresponding to the premises of adhoc, creative, and strategic responsiveness to the field in longitudinal research (Saldana 2003; Patrick 2012). While it was possible to map less-connected PGs, the researchers had to be prepared to face challenges and be proactive. One issue to note is the growing capacity of using social media and virtual space for research purposes (Baltar and Brunet 2012; Kosinski et al. 2015) which proved invaluable for this project and should encourage other youth researchers not to shy away from digital qualitative methodologies.

As already mentioned, trust is pivotal for social research, and particularly critical for long-term involvement in a study (e.g. Saldana 2003; Patrick 2012; Weller 2010; Neale 2017) that comprises multiple interviews over time (QLS). In addition, a retrospective type of recruitment calls for ethical sensitivity (Saldana 2003; Patrick 2012; Neale 2017). The collected data must be safeguarded and the internal confidentiality within a PG might be a serious obstacle when moving on with the next research steps. While the project has undergone ethics commission's assessment and is dedicated to protecting privacy, confidentiality, and anonymity of the participants, making this known to the respondents was not always sufficient. It was quite common for people to say to the insider researcher that they would not have agreed to participate had they not known her personally.
By this logic, field access was difficult, as social trust was not a single (one-off) contract between a researcher and a participant, but rather a multiple (three waves of interviews) contract between the research team, the migrant interviewee (Ego/ Alpha) and their corresponding BetalAlter contacts, thus creating a complex recruitment and social trust research puzzle (see also Patrick 2012). It should be noted that no explicit guidelines on such multi-layered recruitment and long-term involvement are available in the Polish literature thus far, making this work an attempt at cataloguing best practices. We argue that flexibility - both in terms of pragmatic setting of interviews and their channels, and in terms of deciding that not every member of a PG must be reached, for instance - was paramount to our success. Similarly, being reflexive about the process and open about respondents' agency as to how to proceed (see e.g. DeLaine 2000) are believed to serve as good predictors for continuous involvement in the Peer Groups and Migration project.

Our aim here was to predominantly acquire insights into the relevant comparative, non-anonymous population for migrants. While this has been achieved, the heterogeneity of reasons behind recruitment successes and failures indicates a high cost and high gain of concurrently capturing movers and stayers (see also Grabowska et al. 2017a). On the basis of twenty-four PGs and over 130 interviews, we can nevertheless comment on the lives of Polish people born in the 1980s and 1990s. The Peer Groups and Migration QLS has particular implications for studying young Poles in the context of middle-sized towns, as they are clearly entangled in the web of post-1989 transformation and 2004 accession to the European 
Union (Grabowska et al. 2017a; 2017b). The recruitment demonstrated, on the one hand, that they share some commonalities with earlier and elsewhere researched generations (e.g. Strauss and Howe 1991; Howe and Strauss 2009), thus revealing certain collective biographies of Polish youth - within and beyond PGs. On the other hand, the need to resort to so many creative recruitment strategies (Weller 2010; Patrick 2012), should be taken into account by future researchers, with the main conclusion being that young people lead increasingly busy, somewhat chaotic, and spatially scattered lives (see also Amit 2003; Heath et al. 2009; Colvile 2016)

From the recruitment process, it was clear that it was less the role of localities, and more the passage of time (Neale 2017) that fostered similarities across educational backgrounds and accounts of (im)mo-

\section{References}

Adam, Barbara E. 2008. "Future matters: futures known, created and minded." Twenty-First Century Society 3(2):111-116.

Allan, Graham. 1998. “Friendship, sociology and social structure." Journal of Social and Personal Relationships 15(5):685-702.

Allan, Graham. 2011. "Commentary: Friendships and emotions." Sociological Research Online 16(1), 15:1-16.

Amit, Vered., (ed.). 2003. Constructing the field: Ethnographic fieldwork in the contemporary world. London: Routledge.

Arcury, Thomas A. and Sara A. Quandt. 1999. “Participant recruitment for qualitative research: A site- based approach to community research in complex societies." Human Organization 58:128-133. bility that ultimately converged and allowed PGs to be mapped. As our respondents were not anonymous to one another, but rather clustered and linked in a variety of ways through direct PG membership and other socio-demographic characteristics, the recruitment itself revealed the socializing role of a PC (Arnett 2007) in a sense of sharing the research process as part of the aforementioned collective biography of a PG. In sum, while our recruitment methods needed to be creative and somewhat hasty (Weller 2010), the experiences of success and failure in the field aids in seeking constructive and innovative field solutions which fuel methodological knowledge on the Polish youth research landscape. The recruitment process was ultimately worthwhile and rewarding, as it yielded novel insights on the complexities of research relating to youth, peer groups, and migration.

Arnett, Jeffrey J. 2007. "Socialization in Emerging Adulthood From the Family to the Wider World, from Socialization to Self-Socialization." Pp. 208-231 in Handbook of Socialization. Theory and Research, edited by J.E. Grusec, P.D. Hastings. New York: Guilford Press.

Astin, Alexander W. 1993. What matters in college: Four critical years revisited. San Francisco: Jossey-Bass.

Baltar, Fabiola and Ignasi Brunet. 2012. "Social research 2.0: virtual snowball sampling method using Facebook." Internet Research 22/1:57-74.

Berndt, Thomas and Kuenho Keefe. 1995. "Friends' Influence on Adolescents' Adjustment to School." Child Development 66(5):1312-1329.
Colvile, Robert. 2016. The Great Acceleration. How the World is getting Faster, Faster. London: Bloomsbury.

Corsaro, William A., and Donna Eder. 1990. “Children's peer cultures". Annual review of sociology 16(1):197-220

Crosnoe, Robert, Shannon Cavanagh, and Glen H. Elder Ir. 2003. "Adolescent friendships as academic resources: The intersection of friendship, race, and school disadvantage." Sociological perspectives 46(3):331-352.

DeLaine, Marlene. 2000. Fieldwoork, Participation and Practice: Ethics and Dilemmas in Qualitative Research. London, Thousand Oakes, New Delhi: Sage.

Eide, Phyllis and Carol B. Allen. 2005. "Recruiting Transcultural Qualitative Research Participants: A Conceptual Model." International Journal of Qualitative Methods 4(2):1-10.

Fisher, Claude S. 1982. To Dwell Among Friends. Personal Networks in Town and City. Chicago: The Gower

Grabowska, Izabela and Justyna Sarnowska. 2017. "Transnarodowe wielostanowiskowe jakościowe badanie powtórzone w migrujących społecznościach lokalnych [Transnational multisited qualitative longitudinal study in migrating local communities]."Qualitative Sociological Review 13(3):6-28.

Grabowska, Izabela et al. 2017a. _Peer groups and migration. Dialoguing theory and empirical research." Youth Working Papers Series, University of Social Sciences and Humanities. Retrieved November 11, 2017 (http://youth.swps.pl/wp-content/ uploads/2017/04/YWP-No-5_2017.pdf).

Grabowska, Izabela et al. 2017b. Migrants as Agents of Change. Social Remittances in an Enlarged European Union. London: Palgrave Macmillan.

Heath, Sue et al. 2009. Researching young people's lives. London: Sage.

Howe, Neil and William Strauss. 2009. Millennials rising: The next great generation. New York: Vintage.

Jones, Gill. 1999. "The Same People in the same Places? Socio-Spatial Identities and Migration in Youth", Sociology 33:1-22.
Kinney, David A. 1993. "From nerds to normals: The recovery of identity among adolescents from middle school to high school." Sociology of Education 66(1):21-40.

Kosinski, Michal et al. 2015. “Facebook as a Social Science Research Tool: Opportunities, Challenges, Ethical Consideration and Practical Guidelines." American Psychologist 70(6):543-556.

Krings, Torben et al. 2013. New mobilities in Europe. Polish $m$ gration to Ireland post-2004. Manchester, New York: Manchester University Press.

Layder, Derek. 1998. Sociological practice. Linking theory and sociological research. London: Sage.

Lynn-McHale, Debra and Janet A. Deatrick. 2000. “Trust between family and health care provider." Journal of Family Nursing 6(3):210-230.

Males, Mike A. 1996. The scapegoat generation: America's war on adolescents. Monroe, Me: Common Courage Press.

Mannheim, Karl. 1952. “The Problem of Generations." Pp. 276322 in Essays on the Sociology of Knowledge: Collected Works, 5, edited by P. Kecskemeti. New York: Routledge.

McCabe, Janice. 2016. "Friends with Academic Benefits." Contexts 15(3)22-29.

McLean, Carl and Catherine M. Campbell. 2003. “Locating research informants in a multi-ethnic community: Ethnic identities, social networks and recruitment methods." Ethnicity and Health 8(1):41-61.

McLeod, Julie and Rachel Thomson. 2009. Researching Social Change. London: Sage.

Neale, Bren. 2013. “Adding Time into the Mix: Stakeholder Ethics in QL research."Methodological Innovations Online 8(2):6-20.

Neale, Bren. 2017. What is Qualitative Longitudinal Research? London: Bloomsbury.

Neale, Bren and Jennifer Flowerdew. 2003. "Time, texture and childhood: The contours of longitudinal qualitative 
research."International Journal of Social Research Methodology 6(3):189-199.

Neufeld, Anne et al. 2001. "Participation of immigrant women family caregivers in qualitative research." Western Journal of Nursing Research 23(6):575-591.

Ortiz, Steven M. 2001. “How interviewing became therapy for wives of professional athletes: Learning from a serendipitous experience." Qualitative Inquiry 7(2):192-220.

Patrick, Ruth. 2012. “Recruiting \& Sustaining Sample Populations Over Time: Possibilities and Challenges." Timescapes Methods Guides Series Guide 3. ISSN 2049-9248. Retrieved May 22, 2017.

Pilcher, Jane. 1994. "Mannheim's Sociology of Generations: An Undervalued Legacy." British Journal of Sociology 45(3):481-495.

Pustulka, Paula, Justyna Sarnowska, and Izabela Grabowska. Forthcoming." “Grupy rówieśnicze (peer groups) a decyzje migracyjne [Peer groups and migration decision-making]." Rocznik Lubuski.

Ritchie, Jane and Jane Lewis. 2003. Qualitative research practice. London: Sage.

Rugkåsa, Jorun and Krysia Canvin. 2011. “Researching Mental Health in Minority Ethnic Communities: Reflections on Recruitment." Qualitative Health Research 21(1):132-143.

Ruspini, Elisabetta. 2002. Introduction to Longitudinal Research. London: Routledge

Ryan, Allison M. 2000. “Peer groups as a context for the socialization of adolescents' motivation, engagement, and achievement in school." Educational Psychologist 35(2):101-111.

Ryan, Louise, Eleonore Kofman, and Pauline Aaron. 2011. "Insiders and outsiders: working with peer researchers in researching Muslim communities." International Journal of Social Research Methodology 14(1):49-60.
Saldaña, Johnny. 2003. Longitudinal qualitative research: Analyzing change through time. Lanham, MD: AltaMira Press, Rowan \& Littlefield.

Seidman, Irving. 2013. Intervieewing as qualitative research: A guide for researchers in education and the social sciences. New York, London: Teachers College Press.

Skelton, Tracy, Gill Valentine, and Deborah Chambers. 1998. Cool places. Geographies of youth culture. London, New York: Routledge.

Strauss, William and Neil Howe. 1991. Generations. New York: Quill.

Tang, Ning. 2002. “Interviewer and interviewee relationships between women. Sociology 36(3):703-721.

Thomson, Rachel and Julie McLeod. 2015. "New frontiers in qualitative longitudinal research: an agenda for research." International Journal of Social Research Methodology 18(3):243-250.

Thomson, Rachel and Janet Holland. 2003. "Hindsight, foresight and insight: the challenges of longitudinal qualitative research." International Journal of Social Research Methodology 6(3):233-244.

Urberg, Kathryn A., Serdar D. Degirmencioglu, and Colleen Pilgrim.1997. "Close friend and group influence on adolescen cigarette smoking and alcohol use." Developmental Psychology 33:834-844.

Weller, Susie. 2010. "Time(s) to be Creative! Sustaining Young People's Engagement in Qualitative Longitudinal Research." Pp. 34-48 in: Conducting Qualitative Longitudinal Research: Fieldwork Experiences. Working Paper Series, 2, edited by F. Shirani, S. Weller. Leeds: Timescapes,

Willis, Paul. 1977. Learning to labour. How working class kids get working class jobs. Hampshire: Gower.

Youniss, James and Jacqueline Smollar. 1985. Adolescent relations with mothers, fathers, and friends. Chicago: University of Chicago Press.

\section{Citation}

Pustułka, Paula, Natalia Juchniewicz, and Izabela Grabowska. 2017. „Participant Recruitment Challenges in Researching Peer Groups and Migration Retrospectively." Przeglad Socjologii Jakościowej 13(4):48-69. Retrieved Month, Year (www. przegladsocjologiijakosciowej.org). DOI: http://dx.doi.org/10.18778/1733-8069.13.4.04

\section{Wyzwania rekrutacji respondentów $\mathrm{w}$ retrospektywnym badaniu grup rówieśniczych i migracji}

Abstrakt: Artykuł omawia wyzwania rekrutacji respondentów do retrospektywnego badania podłużnego grup rówieśniczych w kontekście upływajacego czasu i mobilności przestrzennej. Opierając się na szerszym jakościowym badaniu w projekcie „Paczk przyjaciół i migracje" w artykule szczegółowo omówiony zostaje proces rekrutacji młodych respondentów w wieku 19-34 lata. Uczestnicy badania pochodzą z trzech miast powiatowych w Polsce i doświadczali migracji tak międzynarodowych, jak i wewnętrznych lub też byli powiązani z rówieśnikami, którzy wyjechali z ich lokalizacji pochodzenia. Respondenci proszeni byli o retrospektywne omówienie czasów swojej młodości/adolescencii, a także o przekazanie kontaktów do członków ich grupy rówieśniczej z okresu gdy mieli 15-19 lat. Na podstawie doświadczeń terenowych w artykule wyróżniono cztery modele rekrutacji grup rówieśniczych. Obok tych modeli wskazano także warianty oraz powody porażek rekrutacyjnych. Artykuł dostarcza praktycznej wiedzy o strategiach rekrutacji uczestników, szczególnie w kontekście budowania szeroko zakrojonego panelu rówieśniczego w ramach jakościowego badania podłużnego.

Słowa kluczowe: rekrutacja respondentów, migracja, grupa rówieśnicza, jakościowe badanie podłużne, badania longitudinaln 